WORK PLAN FOR REGIONAL RECONNAISSANCE FOR

SELECTED HERBICIDES AND NITRATE IN GROUND WATER

OF THE MID-CONTINENT UNITED STATES, 1991

By Dana W. Kolpin and Michael R. Burkart

U.S. Geological Survey

Open-File Report 91-59

Iowa City, Iowa

1991 


\section{U.S. DEPARTMENT OF THE INTERIOR}

MANUEL LUJAN, JR., Secretary

U.S. GEOLOGICAL SURVEY

Dallas L. Peck, Director

For further information write to:

Copies of this report can be purchased from:

U.S. Geological Survey

Box 1230

400 South Clinton Street

Iowa City, Iowa 52244
U.S. Geological Survey

Books and Open-File Reports

Box 25425

Federal Center, Bldg. 810

Denver, Colorado 80225 


\section{CONTENTS}

Page



Introduction.............................................................. 1



Objectives............................................................... 4

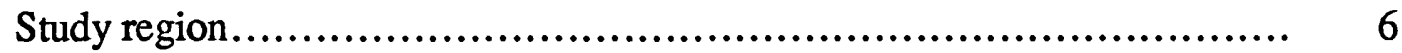



Site selection ............................................................. 6

Map compilation.......................................................... 10

Sampling schedule ....................................................... 10

Sampling equipment and methods.............................................. 11

Labeling, packaging, and shipping............................................. 13

Nutrient analyses .......................................................... 14

Herbicide and atrazine metabolite analyses................................. 14

Data storage ........................................................... 14



Quality assurance ................................................... 14

Selected references........................................................... 15

\section{ILLUSTRATIONS}

Figure 1. Map showing location of wells where atrazine analyses are available in the mid-continent states, from National Water Data Storage and Retrieval System, 1989

Figure 2. Map showing location of contiguous counties in the mid-continent where 25 percent or more of the cropland is in corn and soybean production.

Figure 3. Diagram showing flow chart for site selection for a given aquifer category

\section{TABLES}

Table 1. Partial listing of factors and their sources to be included in the exploratory statistical analysis.

2. Factors used to calculate site distribution ........................... 6

3. Distribution of sampling sites among States in study region ....... 7

4. Guidelines for the number of sites to be selected................... 8

5. Separation of near-surface aquifers by aquifer category ............ 8

6. Site characteristics to be recorded in the Ground-Water Site-

Inventory File .

7. Example of land-use field sheet 
CONVERSION FACTORS

\begin{tabular}{lll} 
Multiply & By & To obtain \\
inch & & \\
foot & 25.4 & millimeter \\
mile & 0.3048 & meter \\
square mile $\left(\mathrm{mi}^{2}\right)$ & 1.609 & kilometer \\
gallon & 2.590 & square kilometer \\
& 3.785 & liter \\
\hline
\end{tabular}




\title{
WORK PLAN FOR REGIONAL RECONNAISSANCE FOR SELECTED HERBICIDES AND NITRATE IN GROUND WATER OF THE MID- CONTINENTAL UNITED STATES, 1991
}

By

\author{
Dana W. Kolpin and Michael R. Burkart
}

\begin{abstract}
An approach was developed to obtain a consistent, regional distribution of herbicide and nitrate data from near-surface aquifers in the corn and soybean producing region of the mid-continent. Near-surface aquifers are defined as those with the top of aquifer material within 50 feet of land surface, regardless of whether the material is saturated or unsaturated. Three hundred wells will be selected for sampling from 12 states. These States include Illinois, Indiana, Iowa, Kansas, Michigan, Minnesota, Missouri, Nebraska, North Dakota, Ohio, South Dakota, and Wisconsin. The reconnaissance data obtained will be used to determine the spatial and seasonal distribution of selected herbicides, two atrazine metabolites, and nitrate in nearsurface aquifers in the study region. Hydrologic, geologic, and land-use data will be collected for use in an exploratory statistical analysis to help explain the herbicide distribution.
\end{abstract}

\section{INTRODUCTION}

The use of agricultural chemicals to improve crop yields in the United States has progressively increased over the past two decades. Twelve mid-continental States (Illinois, Indiana, Iowa, Kansas, Michigan, Minnesota, Missouri, Nebraska, North Dakota, Ohio, South Dakota, and Wisconsin) account for almost 60 percent of the pesticides used nationally (Gianessi and Puffer, 1988). The extensive application of pesticides has created concern for nonpoint-source contamination of surface- and ground-water supplies. Fourteen pesticides, attributed solely to normal agricultural use, have been detected in ground water in these 12 states (Williams and others, 1988).

Analyses of water from selected wells in Minnesota detected pesticides in 33 percent of the 500 wells sampled from June 1985 to July 1986 (Klaseus and others, 1988). Pesticides were most commonly detected in karst, outwash, and shallow alluvial aquifers. The wells were selected from agricultural regions of Minnesota, where the ground water is susceptible to pesticide contamination because of local or regional soils and hydrogeologic conditions or where pesticide or nitrate contamination has occurred.

Analyses of water from irrigation, domestic, and livestock wells from 6 selected areas in Nebraska, detected triazine herbicides in 32 percent of the 57 wells sampled during 1984 (Chen and Druliner, 1987). A preliminary analysis of these samples using multiple regression techniques identified nitrate concentration, irrigation-well density, hydraulic conductivity, specific discharge, well depth, and annual precipitation as being the most statistically significant factors in predicting triazine herbicide concentration. A statewide compilation of ground-water samples in Nebraska indicated that atrazine was by far the most frequently detected herbicide, being detected in 13 percent of the 2260 wells sampled (Exner and Spalding, 1990). 
Water from 20 percent of the 355 municipal wells sampled in Iowa from 1982 to 1987 contained a detectable concentration of at least one pesticide (Detroy and others, 1988). The depths of these wells were less than or equal to 200 feet from land surface. The results of this monitoring program indicate that the percent of pesticide occurrence increase with decreasing well depth. Kolpin and Burkart (1989) performed an exploratory statistical analysis using logistic-regression techniques on 477 samples collected from 1982 to 1987 from 373 municipal wells in Iowa. This study found that the thickness of unconsolidated material from land surface to completion depth was the single most important factor in predicting pesticide occurrence.

Herbicides were detected in 14 percent of the 81 farmstead wells sampled in the Missouri River alluvial aquifer (D. W. Blevins, U.S. Geological Survey, written commun., 1990). Herbicides were detected in 13 percent of the wells sampled from randomly selected GradeA dairy farms in Wisconsin (LeMasters and Doyle, 1989). Pesticides were detected in 9 percent of the 508 samples collected from ground-water monitoring in east central South Dakota (Kimball, 1988). A study of domestic wells in Kansas indicates that 8 percent of the 103 wells sampled had detectable concentrations of pesticides (Steichen and others, 1988). The wells in the Kansas study were sampled from December 1985 through February 1986. Monitoring of municipal wells in Illinois from 1984 to 1987 indicates that 2 percent of the 330 wells sampled for organic compounds contained measurable concentrations of pesticides (Voelker, 1989). The pesticides were detected only in wells open to the unconsolidated sand and gravel aquifers. Monitoring of 46 rural, private wells in 4 Indiana counties indicates that 2 percent of the 400 samples collected contained detectable levels of pesticides (Turco and others, 1988).
While numerous ground-water studies have investigated pesticide contamination on a local scale, few studies have investigated contamination on the regional (multi-state) scale. Existing data from various sources, such as universities and state and federal agencies, cannot be aggregated to present an accurate statement of regional pesticide contamination because data compatibility does not exist among the sources. Data have been analyzed at different laboratories using different laboratory methods, collected during different time periods, sampled using different procedures, and obtained during different climatic conditions. The wells were also selected for different purposes, using different criteria. These factors cause differences among data sets that make simple statistical statements on the aggregated data meaningless and potentially misleading.

A regional statistical examination of pesticide contamination of ground water in the mid-continent states cannot be made even when examining a single data source such as the U.S. Geological Survey's National Water Data Storage and Retrieval System (WATSTORE), one of the largest single sources of pesticide information. The pesticide data in WATSTORE are unevenly distributed, clustered, and have large spatial gaps (fig. 1). These pesticide data also have large temporal variability, partially because of changes in analytical methods and differences among laboratories. The purpose of sampling for pesticides is not documented in WATSTORE. Many samples were collected to confirm known or suspected pesticide contamination and data from these samples cannot be used to determine the extent of contamination from normal use of agricultural chemicals. Sufficient hydrologic and land-use data are not available, on-line, for the WATSTORE sampling sites. For example, wells near agricultural activities cannot be separated from wells near urban or 


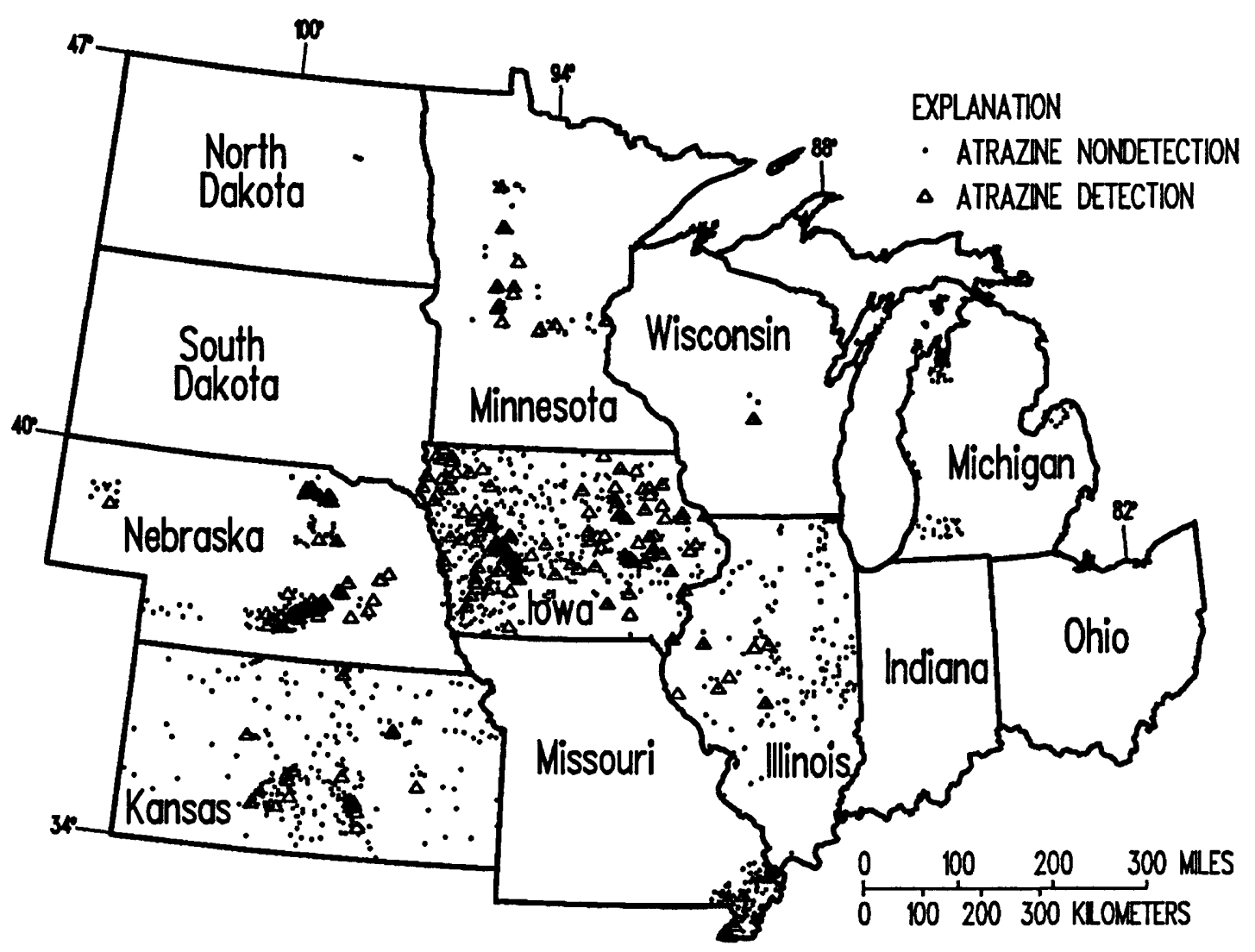

Figure 1. -- Location of wells where atrazine analyses are available in the mid-continent states, from National Water Data Storage and Retrieval System, 1989 (common reporting limit of 0.01 micrograms per liter used).

other land-use areas, and basic hydrologic information, such as geologic unit of the aquifer, is incomplete.

Herbicides and nitrate will be examined in ground water of the mid-continent, for this study. Herbicides are the most frequently detected type of pesticide found in ground water. Ten of the 14 pesticides detected in ground water, attributed solely to normal agricultural use, are herbicides (Williams and others, 1988). The herbicides detected in ground water include the most widely used agricultural chemicals in the mid-continent (Gianessi and Puffer, 1988). Nitrate attributable to nitrogen fertilizer, has been more frequently detected in ground water than pesticides.

\section{PURPOSE}

The purpose of this report is to describe the work plan to establish a regional distribution of wells to obtain reconnaissance data on selected herbicides and nitrate in ground water. These data will be used to determine the spatial and seasonal distribution of nonpoint source herbicide and nitrate contamination in near-surface aquifers of the corn and soybean producing region of the midcontinental states. The reconnaissance sampling will include a complete and consistent set of ancillary data to help draw statistical inferences about the primary factors affecting the seasonal and spatial distribution. 
Several benefits of this study are anticipated: 1) herbicide data will be obtained where currently there are few or no data available; 2) atrazine metabolite (degradation products) data will be obtained across the region where currently almost no data exist; 3 ) the resulting regional data base will minimize internal variability because the wells will be selected from a single set of criteria, samples will be collected by uniform procedures, obtained within a similar time frame, and analyzed by a single laboratory; 4 ) a complete and consistent set of hydrologic and land-use ancillary data will be compiled that can be used for an exploratory statistical analysis to help explain the herbicide data; 5) a framework for future research of nonpoint-source groundwater contamination at subregional scales will be provided.

\section{OBJECTIVES}

The objectives of this reconnaissance are:

1. Determine the spatial and seasonal distribution of selected herbicides, two atrazine metabolites, and nitrate in the near-surface aquifers of the corn and soybean producing region of the mid-continental states (fig. 2).

2. Conduct an exploratory statistical analysis to examine the relations between selected natural and anthropogenic factors and occurrence of herbicides. A partial listing of factors that will be examined is in table 1 .

3 Provide information such as occurrence and concentration of selected herbicides and two atrazine metabolites where little or no data exist currently (1990).

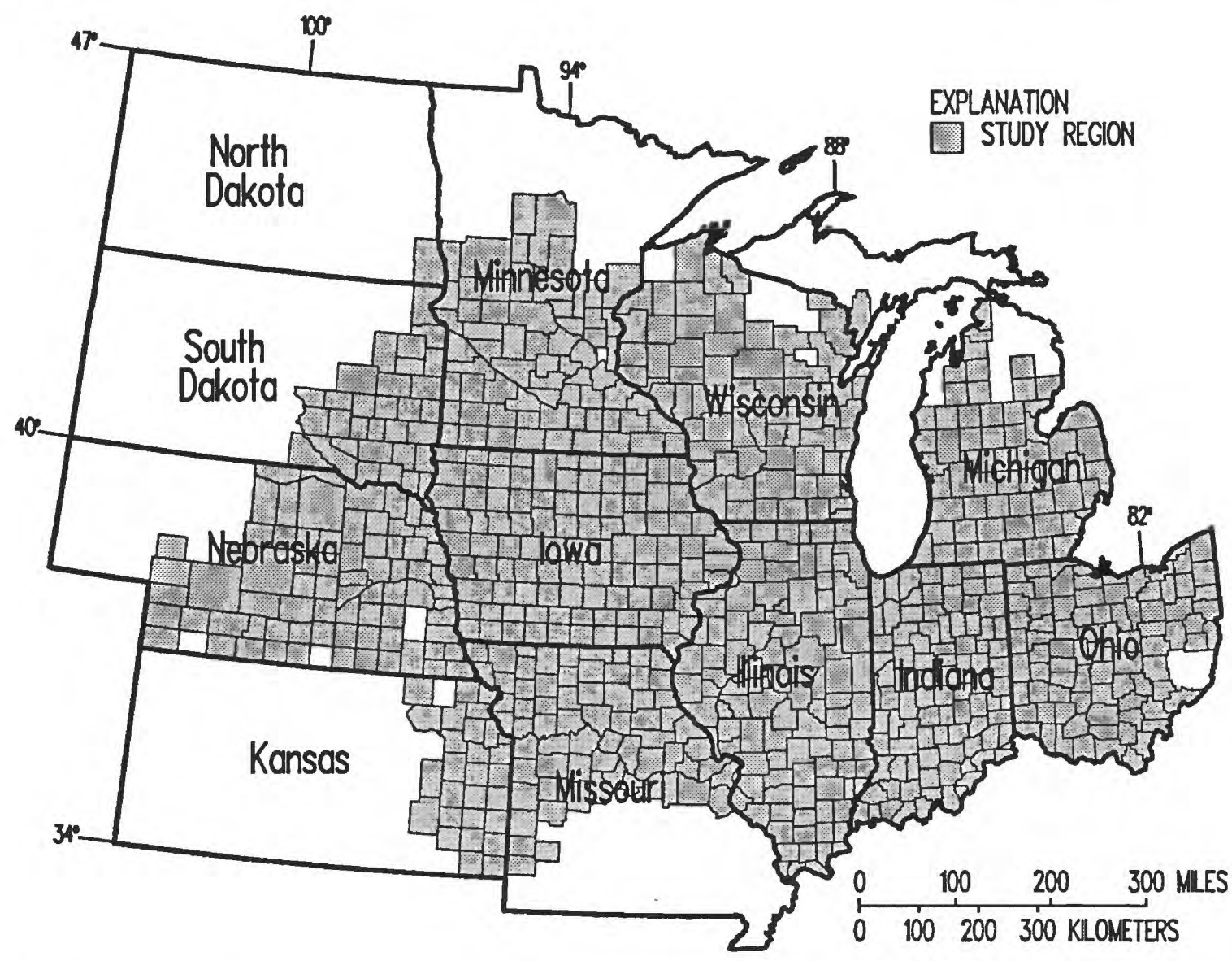

Figure 2. -- Location of contiguous counties in the mid-continent where 25 percent or more of the cropland is in corn and soybean production. 
Table 1.--Partial listing of factors and their sources to be included in the exploratory statistical analysis

[GWSI, Ground-Water Site-Inventory File; ASCS, Agriculture Stabilitzation and Conservation Service; SCS, Soil Conservation Service]

\begin{tabular}{|c|c|}
\hline Factor & Source \\
\hline Well depth & GWSI, well files, owner \\
\hline $\begin{array}{l}\text { Opening interval depth } \\
\text { Land use }\end{array}$ & $\begin{array}{l}\text { GWSI, well files, owner } \\
\text { Field check. ASCS data, topographic maps }\end{array}$ \\
\hline Static water level & $\begin{array}{l}\text { GWSI, field measurement, well files, nearby wells, } \\
\text { owner }\end{array}$ \\
\hline County herbicide use & $\begin{array}{l}\text { Resources For The Future data (Gianessi and Puffer, } \\
\text { 1988), county extension offices, other State or federal } \\
\text { agencies }\end{array}$ \\
\hline Aquifer material & GWSI, well files \\
\hline Season & Field measurement \\
\hline Hydrogeologic position & GWSI, well files \\
\hline Well-construction date & GWSI, well files, owner \\
\hline Precipitation & $\begin{array}{l}\text { National Weather Service, National Oceanographic and } \\
\text { Atmospheric Administration, other precipitation stations }\end{array}$ \\
\hline Land-resource area & Published SCS map \\
\hline Principal soil association & Published or unpublished SCS maps \\
\hline Aquifer category & GWSI, well files \\
\hline Soil permeability & Published or unpublished SCS soil data \\
\hline Nitrate concentration & Water samples collected at site \\
\hline Lithology of overburden & GWSI, well files \\
\hline Primary use of water & GWSI, owner, field check \\
\hline Topographic setting & GWSI, field check \\
\hline Dissolved-oxygen & Field measurement \\
\hline
\end{tabular}

Examples of statistical null hypotheses to be tested include:

1. Herbicides are not detected in near-surface aquifers throughout the corn and soybean producing region of the mid-continent.

2. The occurrence and concentration of herbicides and atrazine metabolites are not significantly different $(\mathrm{p} \leq 0.05)$ between the summer and winter sampling periods.

3. The occurrence and concentration of herbicides and atrazine metabolites are not significantly different ( $p \leq 0.05$ ) between unconsolidated and bedrock aquifer categories.

4. Atrazine is not detected in both the winter and summer sampling periods.
5. The ratio of desethylatrazine to atrazine in ground water are not significantly different $(p \leq 0.05)$ from the ratios in surface water.

6. Herbicides are not detected more frequently in the upper one-half of the aquifer category samples as compared to the lower one-half of the aquifer category samples.

7 Probability of detection cannot be related to selected ancillary factors, such as rate of herbicide application.

8. Herbicide detections are not associated with increased nitrate concentrations.

9. Nitrate concentration cannot be used as a quantitative predictor of herbicide concentrations. 


\section{STUDY REGION}

The study region (fig. 2) is defined as the contiguous counties, in 12 mid-continental states, where 25 percent or more of the cropland is in corn and soybean production (Gianessi and Puffer, 1988). It should be noted that the cropland in a county may be substantially less than the total land area in the county. Consequently, a county with an extremely small quantity of land in crop production but 25 percent or more of those crops are corn and soybeans is included in the study region. This region encompasses the area that is expected to be most affected by potential ground-water contamination from the selected herbicides. The region includes approximately 467,000 square miles in all or parts of Illinois, Indiana, Iowa, Kansas, Michigan, Minnesota, Missouri, Nebraska, North Dakota, Ohio, South Dakota, and Wisconsin.

\section{WORK PLAN}

A work plan consisting of the following elements will be used to accomplish the objectives of this reconnaissance.

\section{Site Selection}

Three hundred sampling sites will be selected from existing wells in the study region. The sampling sites may be observation or production (municipal, domestic, or irrigation) wells. Two weighting factors were used to compute the distribution of sampling sites among the states in the region: (1) the area of near-surface aquifers underlying the study region; and (2) the area of corn and soybeans grown within the study region. The nearsurface aquifer weighting factor represents the area of ground-water resources that may be susceptible to land-surface-applied chemicals. To determine the appropriate weighting factors, U.S. Geological Survey offices in each state were given a list of counties that corresponded to the study region (fig. 2). Using existing hydrogeologic information, the area of nearsurface aquifers (table 2) in each county was calculated independent of the actual area of corn and soybeans in those counties. The nearsurface aquifers are defined as those with the top of aquifer material within 50 feet of land surface, regardless of whether the material is saturated or unsaturated. The near-surface

Table 2.--Factors used to calculate site distribution

\begin{tabular}{lcccc}
\hline & $\begin{array}{c}\text { Near-surface } \\
\text { aquifers in } \\
\text { study region } \\
\text { (square miles) }\end{array}$ & $\begin{array}{c}\text { Corn and } \\
\text { soybeans in } \\
\text { study region } \\
\text { (square miles) }\end{array}$ & $\begin{array}{c}\text { Area in study } \\
\text { region } \\
\text { (square miles) }\end{array}$ & $\begin{array}{c}\text { Total area of } \\
\text { State } \\
\text { (square miles) }\end{array}$ \\
\hline Illinois & 26,012 & 32,059 & 56,400 & 56,400 \\
Indiana & 22,560 & 16,436 & 36,291 & 36,291 \\
Iowa & 14,153 & 33,522 & 56,290 & 56,290 \\
Kansas & 950 & 2,616 & 17,382 & 82,264 \\
Michigan & 25,541 & 6,588 & 36,166 & 58,216 \\
Minnesota & 20,519 & 16,938 & 47,225 & 84,068 \\
Missouri & 26,000 & 11,196 & 46,376 & 69,686 \\
Nebraska & 40,681 & 13,619 & 54,055 & 77,227 \\
North Dakota & 800 & 462 & 1,452 & 70,665 \\
Ohio & 30,763 & 12,017 & 39,213 & 41,222 \\
South Dakota & 7,670 & 5,144 & 24,985 & 77,047 \\
Wisconsin & 30,648 & $\mathbf{7 , 1 5 8}$ & $\mathbf{5 1 , 1 6 1}$ & 56,154 \\
Total & $\mathbf{2 4 6 , 2 9 7}$ & $\mathbf{1 5 7 , 7 5 5}$ & $\mathbf{4 6 6 , 9 9 6}$ & $\mathbf{7 6 5 , 5 3 0}$ \\
\hline
\end{tabular}


aquifers for this study excludes discontinuous, isolated sand and gravel lenses of limited areal extent within a till matrix. The localized nature and potentially large number of these lenses makes regional assessment of them difficult.

The corn and soybean weighting factor represents the quantity of row crops grown where herbicides, particularly atrazine, are estimated to be used most frequently. The area of corn and soybeans (Gianessi and Puffer, 1988) for the counties in the study region also was computed and aggregated by state (table 2). The actual area of corn and soybeans in a state may be less than the area of near-surface aquifers. Indiana, for example, is completely in the study region, which means that at least 25 percent of the cropland in each county is planted in corn or soybeans. There are approximately 16,436 square miles of actual corn and soybeans planted in the State, or 45 percent of the total land area. The area of the State underlain by near-surface aquifers is approximately 22,560 square miles, or 62 percent of the total land area of the State.

The distribution of the 300 sampling sites among the 12 states within the study region is listed in table 3 . The following algorithm was used for the allocation of sampling sites among the states:

$$
S_{i}=\left(\frac{\frac{A q_{i}}{\Sigma A q} \times \frac{C B_{i}}{\Sigma C B}}{\Sigma\left(\frac{A q_{i}}{\Sigma A q} \times \frac{C B_{i}}{\Sigma C B}\right)}\right) \times 300
$$

$$
\text { where } \begin{aligned}
A q_{i}= & \text { area }\left(\mathrm{mi}^{2}\right) \text { of near-surface } \\
& \text { aquifers for each state in } \\
& \text { study region; } \\
\Sigma A q= & \text { total area }\left(\mathrm{mi}^{2}\right) \text { of near-sur- } \\
& \text { face aquifers in study region; } \\
C B_{i}= & \text { area }\left(\mathrm{mi}^{2}\right) \text { of corn and soy- } \\
& \text { beans for each state in study } \\
& \text { region; }
\end{aligned}
$$

$$
\begin{aligned}
\Sigma C B= & \text { total area }\left(\mathrm{mi}^{2}\right) \text { of corn and } \\
& \text { soybeans in study region; and } \\
S_{i}= & \text { number of sampling sites allo- } \\
& \text { cated to each state. }
\end{aligned}
$$

For example, the distribution of sites for Indiana is calculated as follows:

$$
S_{\text {Indiana }}=\left(\frac{\frac{22560}{246297} \times \frac{16436}{157755}}{0.09447}\right) \times 300=30
$$

This algorithm provides equal weighting to the area with near-surface aquifers and the area in corn and soybeans for the purpose of allocating the 300 sampling sites among the states. A sample size of 300 sites was set as the maximum number of wells that could be selected and sampled with the resources available. The sample size will be sufficient for this reconnaissance study to make exploratory investigations of the variability in herbicide occurrence. Table 3.--Distribution of sampling sites
among States in study region

\begin{tabular}{lc}
\hline State & Number of sites \\
\hline Illinois & 68 \\
Indiana & 30 \\
Iowa & 39 \\
Kansas & 1 \\
Michigan & 14 \\
Minnesota & 28 \\
Missouri & 23 \\
Nebraska & 45 \\
North Dakota & 1 \\
Ohio & 30 \\
South Dakota & 3 \\
Wisconsin & 18 \\
Total & $\mathbf{3 0 0}$ \\
\hline The sites will be distributed \\
rologically within two general categories of \\
fers: near-surface unconsolidated and near- \\
ace bedrock. The distribution of wells by \\
fer category (table 4) is based on the near- \\
ace aquifer area supplied by each state,
\end{tabular}


Table 4.--Guidelines for the number of sites to be selected

\begin{tabular}{|c|c|c|c|c|}
\hline \multirow[b]{2}{*}{ State } & \multicolumn{2}{|c|}{$\begin{array}{l}\text { Near-surface } \\
\text { unconsolidated }\end{array}$} & \multicolumn{2}{|c|}{$\begin{array}{c}\text { Near-surface } \\
\text { bedrock }\end{array}$} \\
\hline & $\begin{array}{l}\text { Open interval } \\
\text { in upper one- } \\
\text { half of aquifer }\end{array}$ & $\begin{array}{l}\text { Open interval } \\
\text { in lower one- } \\
\text { half of aquifer }\end{array}$ & $\begin{array}{l}\text { Open interval } \\
\text { in upper one- } \\
\text { half of aquifer }\end{array}$ & $\begin{array}{l}\text { Open interval } \\
\text { in lower one- } \\
\text { half of aquifer }\end{array}$ \\
\hline Illinois & $\overline{23}$ & 22 & 12 & 11 \\
\hline Indiana & 10 & 10 & 5 & 5 \\
\hline Iowa & 11 & 10 & 9 & 9 \\
\hline Kansas & 1 & 0 & 0 & 0 \\
\hline Michigan & 7 & 7 & 0 & 0 \\
\hline Minnesota & 11 & 11 & 3 & 3 \\
\hline Missouri & 5 & 4 & 7 & 7 \\
\hline Nebraska & 22 & 22 & 1 & 0 \\
\hline North Dakota & 1 & 0 & 0 & 0 \\
\hline Ohio & 5 & 5 & 10 & 10 \\
\hline South Dakota & 2 & 1 & 0 & 0 \\
\hline Wisconsin & $\overline{3}$ & 3 & 6 & 6 \\
\hline TOTAL & 101 & 95 & 53 & 51 \\
\hline
\end{tabular}

which is shown is table 5. For example, Illinois has 68 sites (table 3). Using the distribution from table 5,68 sites $\times 0.66$ percentage of unconsolidated aquifer $=45$ unconsolidated aquifer sites and 68 sites $\times 0.34$ percentage of bedrock aquifer $=23$ bedrock aquifer sites. Within each aquifer category, an attempt will be made to chose one-half of the sites from wells that are opened to the upper one-half of the aquifers sampled and one-half of the sites

Table 5.--Separation of near-surface aquifers by aquifer category

\begin{tabular}{lcc}
\hline State & $\begin{array}{c}\text { Unconsolid- } \\
\text { ated aquifer } \\
\text { (percentage) }\end{array}$ & $\begin{array}{c}\text { Bedrock } \\
\text { aquifer } \\
\text { (percentage) }\end{array}$ \\
\hline Illinois & 66 & 34 \\
Indiana & 68 & 32 \\
Iowa & 54 & 46 \\
Kansas & 37 & 63 \\
Michigan & 100 & 0 \\
Minnesota & 79 & 21 \\
Missouri & 41 & 59 \\
Nebraska & 99 & 1 \\
North Dakota & 100 & 0 \\
Ohio & 33 & 67 \\
South Dakota & 100 & 0 \\
Wisconsin & 30 & 70 \\
\hline
\end{tabular}

which are opened tothe lower one-half of the aquifers sampled. This strategy assures vertical distribution of the sampling sites within the aquifers.

The following criteria must be met for a well to be considered a sampling site:

1. A well must be completed in a single aquifer.

2. The 2-mile radius around a well is planted with more than 25 percent corn or soybeans.

3. The sampling point is before any water treatment and, if possible, pressure or holding tanks.

4. The well owner's permission must be obtained to flush well, sample well, and release data.

5. The well was not installed to confirm a known or suspected herbicide, nitrate, or organic contaminant.

The following information must be known for a well to be considered a potential sampling site:

1. Exact well location. 
2. Aquifer material (for example, carbonate rock, sand and gravel, or sandstone).

3. Well depth.

4. Depth to top and bottom of the open interval.

5. Depth to top of aquifer material (saturated or unsaturated).

6. Aquifer thickness.

7. Approximate static water level.

8. Lithology and thickness of overlying materials from strip logs or driller's logs.

Before site selection, four random lists of counties in the study region will be generated for each state using county Federal Information Processing Standards (FIPS) codes. One list will be used for each of the four categories of aquifers (table 4). The order of aquifer categories for which sites will be selected are: (1) near-surface unconsolidated; open interval lower one-half of aquifer, (2) near-surface unconsolidated; open interval upper one-half of aquifer; (3) near-surface bedrock; open interval lower one-half of aquifer; and (4) near-surface bedrock; open interval upper one-half of aquifer. The process outlined in the flow chart (fig. 3) will be used by the states for selection of wells within each of the four aquifer categories. This flow chart follows a series of decision levels to ensure efficient and uniform site selection. Twice the number of sites given in tables 3 and 4 will be selected for each state, one primary and one alternate well. The primary and alternate wells are selected to obtain wells representative of the aquifer. The sites should not be selected because of convenient location. The lists of candidate sites will be obtained from U.S. Geological Survey Ground-Water Site-Inventory files (GWSI), state and county records, and other available sources of information.

The search for wells should commence at the center of each identified county, or as close to the center as the aquifer boundaries allow,



Figure 3.-- Flow chart for site selection for a given aquifer category 
and expand radially outward. From the available pool of wells, the first well that meets the specified aquifer type, position, and qualifying criteria will be designated as the primary well. The second well will be designated as the alternate well. Once two appropriate wells have been located, the search in that county is terminated. If two suitable wells cannot be located in a county, then that county is excluded. The site selection process proceeds county-by-county through the random FIPS code list until the desired number of counties (each having two selected wells) for that aquifer category and state (table 4 ) is achieved. The process is repeated for each of the four aquifer categories. During the selection process, care should be taken to ensure that no primary or alternate wells are within 4 miles of each other. If any sites are too close, one of the wells selected will not be used, a new well will be selected, and distances will be rechecked. The distance verification will ensure that two wells measuring the "same water" are not used. For example, if the primary and alternate well were located within 4 miles of each other, there would be overlap of land-use within the designated two-mile radius. A local problem (point source, dump, etc.) discovered later could then affect both the primary and alternate well, requiring the selection of another site.

Each of the four random lists will be used only once. When the bottom of any of the four random FIPS code lists is reached and a full set of wells for that aquifer category has not been selected, the following procedures will be observed:

1. For near-surface unconsolidated, open interval lower one-half of aquifer, the number of unselected sites will be added to category of near-surface unconsolidated, open interval upper one-half of aquifer.

2. For near-surface unconsolidated, open interval upper one-half of aquifer, the project team will be contacted for instructions.
3. For near-surface bedrock, open interval lower one-half of aquifer, the number of unselected sites will be added to category of near-surface bedrock, open interval upper one-half of aquifer.

4. For near-surface bedrock, open interval upper one-half of aquifer, the project team will be contacted for instructions.

Complete notes documenting the selection process will be maintained by each state. Lists of selected wells will be examined and reviewed by the project team for final approval.

Once the sampling sites have been selected and approved, site characteristics will be collected and recorded in the GWSI to the extent possible (table 6). A field form, modified from Hardy and others (1989, p. 6-7), will be used by each state to record characteristics and field observations of land-use information (table 7, end of text). Other necessary information to be collected not listed in tables 6 and 7 is listed in table 1.

\section{Map Compilation}

Each state will generate a map showing the boundaries of the near-surface unconsolidated aquifers, excluding discontinuous sand lenses of limited areal extent, and bedrock aquifers that were used to obtain the information in tables 2 and 5. The maps will be used to establish general hydrogeologic boundaries within the region. All sources used to produce these aquifer maps will be documented by the state. These maps will be generated at the scale of 1:2,500,000.

\section{Sampling Schedule}

Two sets of samples will be collected for this reconnaissance. The first sample collection will be in March 1991, before the application of agricultural chemicals. The second sample collection will be during the growing season, June to July 1991, after the application of 
agricultural chemicals. Sample collection can be timed to coincide with regularly scheduled field trips when possible; however, special trips may be required for some of the collection. Each sample collection will be completed across the study region within a 5-week period to prevent time-related factors from affecting interpretation of the spatial variation in pesticide occurrence.

\section{Sampling Equipment and Methods}

Sampling equipment will vary according to the type of well at each site. Recommended samplers are described by and should be selected in the order discussed in Hardy and others $(1989$, p. 22). Other types of samplers are allowed if constructed of appropriate materials. The sample water should only come in contact with glass, teflon, or stainless steel. All tubing for the pump and filter apparatus should be teflon or teflon coated, but silicon rubber tubing within the peristaltic pump is acceptable. Plate filters that are in current use will be adequate for the pumps. Equipment will be cleaned before initial use.

A water-quality checklist will be sent to the states before sampling. The following steps will be followed when the wells are sampled.

1. Before sampling begins:

a. Complete land-use field sheet (table 7).

b. Perform instrument maintenance and calibration (Wood, 1981).

Table 6.-- Site characteristics to be recorded in the Ground-Water Site-Inventory File

\begin{tabular}{|c|c|c|c|}
\hline Code & Site characteristic & Code & Site characteristic \\
\hline $\begin{array}{l}\text { C1 } \\
\text { C2 }\end{array}$ & $\begin{array}{l}\text { Site ID (station number) } \\
\text { Type of site }\end{array}$ & C84 & $\begin{array}{l}\text { Depth to bottom of open interval, } \\
\text { in feet }\end{array}$ \\
\hline C3 & Data reliability & C91 & Depth to top of geohydrologic \\
\hline $\mathrm{C} 4$ & Agency code & & unit, in feet (for each unit) \\
\hline C5 & Project number & C92 & Depth to bottom of geohydrologic \\
\hline C6 & District code & & unit, in feet (for each unit) \\
\hline $\begin{array}{l}\text { C7 } \\
\text { C8 }\end{array}$ & $\begin{array}{l}\text { State code } \\
\text { County code }\end{array}$ & C93 & $\begin{array}{l}\text { Lithologic unit identifier (for each } \\
\text { unit) }\end{array}$ \\
\hline C9 & Latitude & C235 & Date water level measured \\
\hline $\begin{array}{l}\mathrm{C} 10 \\
\mathrm{C} 11\end{array}$ & $\begin{array}{l}\text { Longitude } \\
\text { Latitude-longitude accuracy code }\end{array}$ & C237 & $\begin{array}{l}\text { Water level, in feet below land } \\
\text { surface }\end{array}$ \\
\hline $\mathrm{C} 12$ & Local well number & C238 & Status of well at time of water-level \\
\hline C16 & Altitude of land surface, in feet & & \\
\hline $\begin{array}{l}\text { C17 } \\
\text { C18 }\end{array}$ & $\begin{array}{l}\text { Method used to determine altitude } \\
\text { Accuracy of altitude }\end{array}$ & C239 & $\begin{array}{l}\text { Method used to measure water } \\
\text { level }\end{array}$ \\
\hline C19 & Topographic s & C268 & Rated capacity of lifting device, in \\
\hline C23 & Primar & & gallons per minute \\
\hline $\begin{array}{l}\text { C24 } \\
\text { C27 }\end{array}$ & $\begin{array}{l}\text { Primary use of water } \\
\text { Hole depth (depth dri }\end{array}$ & $\mathrm{C} 276$ & Accuracy of water-level \\
\hline $\mathrm{C} 28$ & $\begin{array}{l}\text { Depth of well (finished depth), } \\
\text { in feet }\end{array}$ & C321 & $\begin{array}{l}\text { Begin date for use of water-level } \\
\text { measuring point }\end{array}$ \\
\hline $\begin{array}{l}\text { C29 } \\
\text { C43 }\end{array}$ & $\begin{array}{l}\text { Source of depth data } \\
\text { Type of lift }\end{array}$ & C322 & $\begin{array}{l}\text { End date for use of water-level } \\
\text { measuring point }\end{array}$ \\
\hline $\begin{array}{l}\text { C60 } \\
\text { C65 }\end{array}$ & $\begin{array}{l}\text { Date of completed well construction } \\
\text { Method of contruction }\end{array}$ & C323 & $\begin{array}{l}\text { Height of water-level measuring } \\
\text { point }\end{array}$ \\
\hline $\begin{array}{l}\text { C66 } \\
\text { C67 }\end{array}$ & $\begin{array}{l}\text { Type of finish } \\
\text { Tyne of surface seal }\end{array}$ & C324 & Description of water-level \\
\hline $\mathrm{C} 80$ & $\begin{array}{l}\text { 1ype of surtace } \\
\text { Casing material }\end{array}$ & & Aquifer-type code \\
\hline r & Depth to top of open interval, in feet & C714 & Primary aquifer \\
\hline
\end{tabular}


c. Where possible, measure and record water levels (before pumping).

d. Calculate quantity of 3-casing volumes of water for observation wells, based on formula in Hardy and others (1989, p. 19).

2. Sample procedure for wells.

a. Purge well.

1) Water-supply well:

- If well is not in current use, pump well at least 20 minutes.

2) Observation well:

- Lower pump 18 inches below water level and begin pumping;

- pump at least 3 casing volumes of water;

- lower pump to mid-point of well opening and remove an additional 2 gallons of water (make sure sediment at bottom of well is not disturbed).

b. Test for chemical stability:

1) Make three successive measurements at 5 -minute intervals of index parameters (specific conductance, $\mathrm{pH}$, and water temperature) using flow-through chambers.

2) Chemical stability is reached when successive measurements of index parameters differ less than:

- specific conductance (5 percent),

- $\mathrm{pH}$ (0.1 unit),

- water temperature ( 0.2 degree Celsius).

3) Use last measurements of index parameters as field measurements of specific conductance, $\mathrm{pH}$, and water temperature. c. Measure dissolved oxygen concentration using flow-through chambers and a dissolved-oxygen meter (preferred) or the Winkler method.

d. Collect a sufficient volume of water by either of the following methods:

1) Switch tubing from flow-through chamber to plate-filter apparatus.

2) Collect water in glass bottles or teflon churn splitter.

e. Collect a one-liter bottle of raw water for possible tritium analysis (summer sample collection only).

f. Flush at least 250 milliliters of sample water through 0.45 micrometer acetate filter. Use tweezers to handle filter. Use a peristaltic pump if sample is collected in appropriate containers.

g. Rinse a 250 milliliter brown polyethylene bottle with a few milliliters of filtered sample, fill it to within a few milliliters of the top, and add one ampule of mercuric chloride (preservative for nitrate analysis).

h. Remove acetate filter, rinse apparatus with deionized water, install 1.0 micrometer glass-fiber filter, and reassemble apparatus. Use tweezers to handle filter.

i. Flush at least 250 milliliters of sample water through 1.0 micrometer glassfiber filter and fill two 125 milliliter amber, baked-glass bottles with filtered sample water for herbicide analysis.

j. Immediately place all samples on ice, except the sample for tritium analysis.

3. Post-sample decontamination:

a. Remove the filter from plate-filter apparatus.

b. Pump 500 milliliters of deionized water through the plate-filter apparatus. 
c. If the pump was lowered into well:

1) pump air pocket into tubing to mark end of sample water,

2) pump until sample water evacuated,

3) flush by pumping deionized water,

4) rinse tubing with deionized water.

d. Rinse out any sediment remaining in the flow-through chamber.

4. End-of-day decontamination.

a. Mix laboratory detergent and water to manufacturer's specifications. Container can be a tube or cylinder closed at one end in which the pump can be inserted.

b. Place pump in detergent water, place discharge hose back into container to recirculate detergent and pump for 3 to 5 minutes. Set pump to reverse for a few minutes to flush intake chamber.

c. Remove detergent water and pump with deionized water to flush detergent from tubing. Do not recirculate rinse water. Rinse until all soap bubbles are removed. Reverse flow to rinse out intake chamber.

d. Disassemble and scrub plate filter apparatus with detergent. Rinse with plenty of deionized water and leave disassembled overnight to dry.

\section{Labeling, Packaging and Shipping}

All bottles should be labeled with state, station ID number, station name (if applicable), sample date, sample time, sample type (reg=regular, dup=field duplicate, blank=field blank, spike=lab spike) and "GW Recon". For example:



Make sure the label will not be removed or become smeared if it gets wet. Place 125milliliter glass bottles in sealed sandwich bags ( 2 bottles per bag). The bags should then be placed in foam sleeves to minimize breakage. All samples, except tritium, should be chilled immediately after collection and shipped within 5 days to appropriate laboratory.

The 250 milliliter brown plastic bottles for nutrient analysis should be sent to:

\section{U.S. Geological Survey \\ National Water Quality Lab \\ 5293 Ward Road-B \\ Arvada, CO 80002}

Include a completed Log Inventory form with the nutrient sample (schedule 400).

The 125 milliliter glass bottles for herbicide analysis should be sent to:

E. Michael Thurman

U.S. Geological Survey

4821 Quail Crest Place

Lawrence, Kansas 66049

The one-liter glass bottles should be placed in a foam sleeve and sent to:

Dana Kolpin

U.S. Geological Survey

400 S. Clinton St.

Iowa City, Iowa 52244

A copy of all field information: completed field sheets, and water-quality check list should be sent to:

Dana Kolpin

U.S. Geological Survey

400 S. Clinton St.

Iowa City, Iowa 52244 


\section{Nutrient Analyses}

Samples from all sites will be analyzed for the following nutrients by the USGS central laboratory in Arvada, Colorado: (1) nitrite, dissolved as $\mathrm{N}$ (laboratory code 0160, WATSTORE code 00613); (2) nitrite plus nitrate, dissolved as $\mathrm{N}$ (laboratory code 0228 , WATSTORE code 00631); (3) nitrogen, ammonia, dissolved as $\mathrm{N}$ (laboratory code 0301, WATSTORE code 00608); and (4) phosphorus, dissolved orthophosphate, as $\mathrm{P}$ (laboratory code 0162, WATSTORE code 00671).

\section{Herbicide and Atrazine Metabolite Analyses}

Samples from all sites will be shipped to the Kansas District laboratory for gas chromatography/mass spectrometery (GC/MS) analysis. Herbicides to be analyzed for include alachlor, ametryn, atrazine, cyanazine, metolachlor, metribuzin, prometon, prometryn, propazine, and simazine. Two atrazine metabolites (desethylatrazine and deisopropylatrazine) also will be analyzed. The herbicides will be isolated using solid-phase extraction. After extraction, the samples will undergo a GC/MS analysis. The GC/MS reporting limit for all herbicides is 0.05 micrograms per liter $(\mu \mathrm{g} / \mathrm{L})$, except for cyanazine which is $0.2 \mu \mathrm{g} / \mathrm{L}$.

\section{Data Storage}

All data collected for this reconnaissance will be stored electronically to provide accessibility for general retrieval. The data for each state will be on their computer system and the data for the entire network will be centrally located in a Geographic Information System (GIS) data base. The following explains how and where the general types of information collected will be stored:
1. Site information: hydrologic, geologic, and physical characteristics of the sampling sites will be entered by each state into GWSI (WATSORE).

2. Water-quality information: all laboratory water-quality analyses and field measurements will be entered by each state into the Water-Quality Database (QWDATA in WATSTORE).

3. Land-use information: Software will be developed, similar to Scott (1989), for interactive storage and retrieval of the landuse information compiled from table 7 . Each state will be responsible for entering the land-use data into the data base system.

4. Miscellaneous information: Other various factors including precipitation, soil data, and fertilizer and herbicide application, will either be compiled by the project team or gathered by the states and sent to the project team for entry into the central GIS data base.

\section{Products}

Several products are anticipated from the results of this study:

1. One or more journal articles

2. A USGS Open-File report containing data analyses

3. A USGS Water-Resources Investigations Report containing interpretative analyses

4. A GIS data base

The results of the laboratory analyses will be released in two separate intervals following each sample collection when all the laboratory results are complete, checked, and finalized.

\section{QUALITY ASSURANCE}

Quality assurance efforts for the reconnaissance will be in two parts: a laboratory program and a field program. The 
laboratory program will be the responsibility of the servicing laboratory. The field program will consist of the following:

1. Six percent of the nutrient and GC/MS samples will be field duplicates. The duplicate samples will be collected in separate containers immediately following the regular sample. The plate-filter apparatus will be decontaminated and the duplicate sample processed as if it were another site. Each state will have at least one nutrient and one GC/MS duplicate. The duplicate sites will be randomly selected prior to sampling by the project team.

2. Three percent of the nutrient and GC/MS samples will be field blanks. The field blanks will be processed at the site before collection of the regular ground-water samples. Blanks will consist of deionized water pumped through the plate-filter apparatus after decontamination. Each District will have at least one nutrient and one GC/MS field blank to be selected prior to sampling by the project team.

3. One percent of the GC/MS analyses will consist of spike samples. Selected states will be furnished two 125 milliliter glass bottles containing water of known herbicide concentration to be submitted for $\mathrm{GC} / \mathrm{MS}$ analysis.

\section{SELECTED REFERENCES}

Chen, Hsiu-Hsiung, and Druliner, A. D., 1987, Nonpoint-source agricultural chemicals in ground water in Nebraska--Preliminary results for six areas of the high plans aquifer: U.S. Geological Survey Water-Resources Investigation Report 86-4338, 68 p.

Detroy, M. G., Hunt, P. K. B., and Holub, M. A., 1988, Ground-water-quality monitoring program in lowa -- Nitrate and pesticides in shallow aquifers: U.S. Geological Survey Water-Resources Investigation Report 88$4123,31 \mathrm{p}$.
Exner, M. E., and Spalding, R. F., 1990, Occurrence of pesticides and nitrate in Nebraska's ground water: Water Center, Institute of Agriculture and Natural Resources, and The University of Nebraska, $34 \mathrm{p}$.

Gianessi, L.P., and Puffer, C.M., 1988, Use of selected pesticides for agricultural crop production in the United States 1982-1985: Washington, D.C., Resources for the Future, Inc., Quality of the Environment Division, $490 \mathrm{p}$.

Hardy, M.A., Leahy, P.P., and Alley, W.M., 1989, Well installation and documentation, and ground-water sampling protocols for the pilot National Water-Quality Assessment Program: U.S. Geological Survey Open-File Report 89-396, 36 p.

Kimball, C. G., 1988, Temporal and spatial distribution of ground water contaminants attributed to agricultural practices, in Agricultural Impacts On Ground Water - A Conference, Des Moines, Iowa, 1988, Proceedings: Association of Ground Water Scientists and Engineers, p. 59.

Klaseus, T. G., Buzicky, G. C., and Schneider, E. C., 1988, Pesticides and groundwater: surveys of selected Minnesota wells: Minneapolis, Minnesota, Minnesota Departments of Health and Agriculture, Report to the Legislative Commission on Minnesota Resources, $95 \mathrm{p}$.

Kolpin, D. W., and Burkart, M. R., 1989, Indicators of pesticides in shallow aquifers in Iowa. U.S. Geological Survey Second National Symposium on Water Quality: Abstracts of the Technical Sessions, Orlando, Florida, November 12-17, 1989, U.S. Geological Survey Open-File Report 89-409. p. 47. 
LeMasters, Gary., and Doyle, D. J., 1989, Grade A dairy farm well water quality survey: Madison, Wisconsin, Wisconsin Department of Agriculture, Trade and Consumer Protection, and Wisconsin Agricultural Statistics Service, $36 \mathrm{p}$.

Scott, J. C., 1989, A computerized data-base system for land-use and land-cover data collected at ground-water sampling sites in the pilot National Water-Quality Assessment Program: U.S. Geological Survey Water-Resources Investigations Report 89$4172,139 \mathrm{p}$.

Steichen, James, Koelliker, James, Grosh, Doris, Heiman, Alan, Yearout, Robert, and Robbins, Victor, 1988, Contamination of farmstead wells by pesticides, volatile organics, and inorganic chemicals in Kansas: Ground-Water Monitoring Review Summer 1988, volume 8, number 3, p. 153-160.

Turco, R. F., and Konopka, A. E., 1988, Agricultural impact on groundwater quality: Water Resources Research Center, West Lafayette, Indiana, Purdue University, Technical Report 185, 56 p.
Voelker, D. C., 1989, Quality of water from public-supply wells in principal aquifers of Illinois, 1984-87: U.S. Geological Survey Water-Resources Investigations Report 884111, 29 p.

Williams, M. W., Holden, P. W., Parsons, D. W., and Lorber, M. N., 1988, Pesticides in ground water data base 1988 interim report: U.S. Environmental Protection Agency, Office of Pesticide Programs, Environmental Fate and Effects Division, and Environmental Fate and Ground Water Branch, 43 p.

Wood, W. W., 1981, Guidelines for collection and field analysis of ground-water samples for selected unstable constituents: U.S. Geological Survey Techniques of WaterResources Investigations, Book 1, Chapter D2, 24 p. 
Table 7.-- Example of land-use field sheet

\section{Land Use Field Sheet - Ground Water Reconnaissance}

Date

Inspector

Site ID

1. Topographic Setting

(alluvial fan, local

depression, dunes, flat surface, flood plain, hilltop, sinkhole, marsh, hillside, alluvial terrace, undulating, valley flat, upland draw - description in Watstore Manual v. 2, chap. II, p. 8-19)

2. Land-Use Classification - Identify the land use within the specified radius of the well and estimate its percent of the total area $(0-25,26-50,51-75,76-100)$

\begin{tabular}{|l|l|l|l|l|}
\hline Land Use & $\mathbf{< 1 0 0}$ feet & $\mathbf{< 0 . 2 5}$ mile & $\mathbf{0 . 2 5}$ to $\mathbf{2}$ miles & Comments \\
\hline Urban & & & & \\
\hline -Residential & & & & \\
\hline -Commercial & & & & \\
\hline -Industrial & & & & \\
\hline -Other (specify) & & & & \\
\hline Agricultural & & & & \\
\hline -Row crops & & & & \\
\hline -Irrigated & & & & \\
\hline -Nonirrigated & & & & \\
\hline -Other cropland & & & & \\
\hline -Pasture & & & & \\
\hline -Orchard, vineyard & & & & \\
\hline -Other (specify) & & & & \\
\hline Rangeland & & & & \\
\hline Forest & & & & \\
\hline Wetland & & & & \\
\hline Water & & & & \\
\hline Barren & & & & \\
\hline
\end{tabular}

3. Agricultural Practices - Describe agricultural practices within a 2-mile radius of sampled well.

a. Extent of irrigation - Circle applicable statement

nonirrigated, supplemental irrigation in dry years only, irrigated

b. Crop and animal types - Provide information on present crop (corn, soybeans, wheat, alfalfa, etc.) and animal (cattle, hogs, etc.) types to the extent possible. 
Table 7.-- Example of land-use field sheet--Continued

\section{Land-Use Field Sheet - Continued}

4. Local Features - Identify local features within the specified distances than may affect groundwater quality of the sampled well.

\begin{tabular}{|l|l|l|l|}
\hline Feature & $<0.25$ mile & $\mathbf{0 . 2 5}$ to 2 miles & \\
\hline Chemical plant & & & \\
\hline Waste disposal pond & & & \\
\hline Landfill & & & \\
\hline Golf course & & & \\
\hline Stream, river & & & \\
\hline Irrigation canal & & & \\
\hline Drainage ditch & & & \\
\hline Lake & & & \\
\hline Reservoir & & & \\
\hline Spring & & & \\
\hline Mine, quarry, gravel pit & & & \\
\hline Farm building & & & \\
\hline Abandoned well & & & \\
\hline Grain elevator & & & \\
\hline Feedlot & & & \\
\hline Septic field & & & \\
\hline Sinkhole & & & \\
\hline Other (specify) & & & \\
\hline Other (specify) & & & \\
\hline Other (specify) & & & \\
\hline
\end{tabular}

5. Pesticide Handling at Wellhead - Document pesticide handling practices at the wellhead

a) Have pesticides been mixed at the wellhead (present or in the past)

b) Have pesticide containers been rinsed at the wellhead (present or past)

c) Has an accident ever occurred at the wellhead (spills, back siphoning, etc.)

6. Additional Comments - Emphasize factors that might affect local ground-water quality 